\title{
Entre olhares: tempo e intercâmbios culturais nas imagens da Ilha do Maranhão
}

\author{
JOSÉ OLIVEIRA DA SILVA FILHO
}

\section{Resumo}

O artigo trata das sobrevivências de imagens presentes em representações iconográficas da cidade de São Luís do Maranhão, em diferentes suportes, tomando por base a noção de "origem" desenvolvida por Walter Benjamin no intuito de discutir a ideia de uma visualidade sobre a cidade que vem sendo reinventada em diferentes épocas evidenciando trocas heterogêneas de olhares e temporalidades, de modo a revelar um processo de restauração de imagens primitivas sempre atualizadas. 


\title{
Between looks: time and cultural exchanges in images of Maranhão Island
}

\begin{abstract}
The article is about the survival of imagery that is present in iconographic representations of the city of São Luís of Maranhão. In distinct supports and by using as a foundation the notion of "origin" developed by Walter Benjamin, it discusses the idea of a visuality of the city that has been reinvented in different periods of time, showing heterogeneous exchanges of glances and time frames in order to reveal a primitive imagery restoration process that is always updated.
\end{abstract}




\section{Entre miradas: tiempo e intercambios culturales en las imágenes de la Isla de Maranhão}

JOSÉ OLIVEIRA DA SILVA FILHO

\section{Resumen}

El artículo aquí presentado trata sobre la sobrevivencia de las imágenes presentes en las representaciones iconográficas, en diferentes soportes, de la ciudad de São Luís do Maranhão. Lo anterior, tomando como base la noción de "origen" desarrollada por Walter Benjamin, ello con el objetivo de discutir la idea de una visualidad sobre una ciudad que viene siendo reinventada en diferentes épocas y que evidencia intercambios heterogéneos de miradas y temporalidades, revelando así un proceso de restauración de imágenes primitivas siempre actualizadas. 
$E_{\text {m } 1908 \text { passeava pelos salões do pavilhão dos Estados, local }}$ situado na Praia Vermelha no bairro da Urca na então Capital Federal, o poeta e teatrólogo maranhense Artur Azevedo. Naquele momento a cidade do Rio de Janeiro sediava a Exposição Nacional, que tinha como motivação comemorativa o centenário da Abertura dos Portos. Radicado em terras cariocas desde 1873, ano em que partira de São Luís do Maranhão, este atuou como um dos agentes responsáveis por julgar a qualidade dos trabalhos expostos naquele evento. Em sua primeira visita aos estandes, ao visitar o espaço destinado à exibição dos produtos vindos do Maranhão, deteve-se por alguns minutos a contemplar o luxuoso álbum de fotografias elaborado pelo hábil fotógrafo Gaudêncio Cunha que havia sido contratado pelo governo do Estado do Maranhão especialmente para conceber a obra. Segundo o comissário maranhense Domingos Perdigão, este, após folhear todas as páginas do álbum teria pronunciado a seguinte frase "cheguei agora do Maranhão, está muito melhorada a minha terra, mais ainda a conheço bem". (SILVA FILHO, 2012, p.12)

A viagem imaginária de Azevedo serve para refletirmos acerca das múltiplas temporalidades que comportam o universo das imagens. Ao contemplar as fotografias no álbum, este reconhece a cidade que foi, e aquela que permanece, remontando toda uma trama visual em constante transformação assim como o tecido urbano das cidades.

O filósofo e historiador da arte George Didi-Huberman defende a necessidade do historiador ao deter-se sobre a análise das imagens, que este, realize um verdadeiro esforço arqueológico a fim de que possa descobrir o "tempo da imagem, ou tempo na imagem" (DIDI-HUBERMAN, 2012, p. 69.). Para Huberman a "fotografia está em parte ligada a imagem e a me- 
mória: possui por isso o seu eminente poder epidérmico" (DIDI-HUBERMAN, 2012, p.39). Para que possamos compreender os sentidos das imagens será mesmo necessário revirar as camadas da memória histórica que foi e continua sendo construída pelo "inconsciente óptico" que continuamente vem se forjando (BENJAMIN, 1985, p. 94). Benjamin em seu clássico Pequena história da fotografia nos chama atenção para a necessidade de nos concentrarmos num estudo da "arte como fotografia" e não o contrário. Ir em busca do conteúdo artístico da fotografia significa ir a procura de um contínuo processo de constituição marcado por diferentes camadas sobrepostas nas diferentes instâncias do tempo. Freud ao comparar a mente humana com as camadas de história existentes na cidade de Roma, reforça a alegoria do historiador como antropólogo que deve revirar as diversas camadas formadas pelo tempo.

Como porta de entrada para nossa análise, detenho-me a uma imagem que ganha destaque no álbum do fotógrafo Gaudêncio Cunha ao ocupar inteiramente uma das páginas do seu álbum. Refiro-me a página, mas também poderíamos chamá-la de prancha, já que esta, devido ao seu grandioso formato mais se parece com esta última denominação. Com capa em couro trabalhado e letras douradas gravadas, o álbum, apresentava-se em um grande formato e contendo diversas dessas pranchas, traduzindo-se numa espécie de metonímia do Estado do Maranhão.

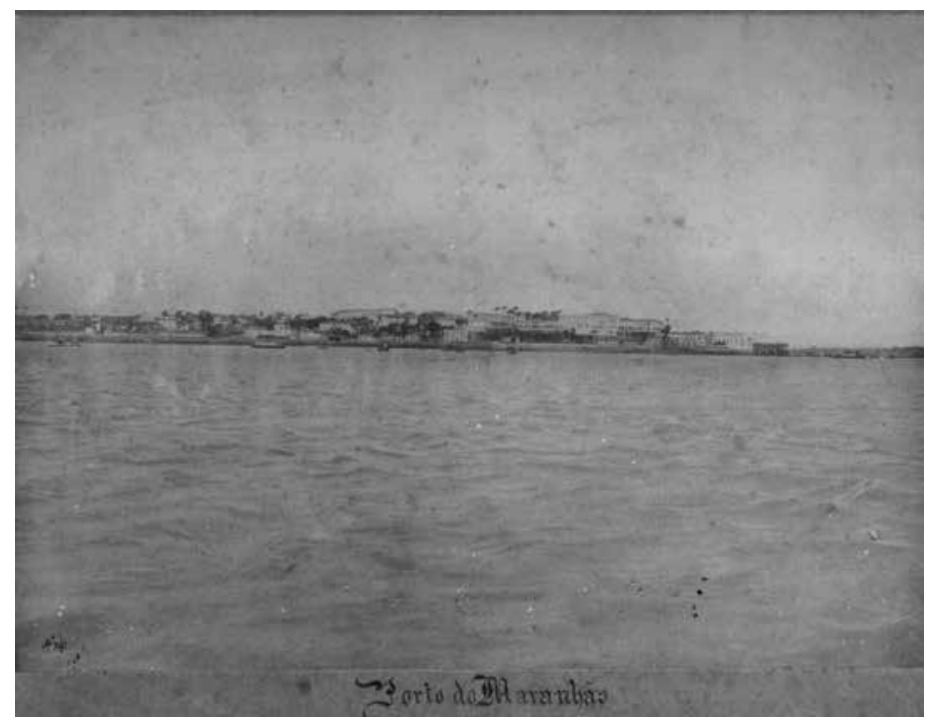


Funcionando como uma espécie de grande panorâmica da silhueta do continente, a imagem acima, pode ser percebida com ponto de chegada, expresso imediatamente pela denominação de sua legenda "Porto do Maranhão", dado ao caráter de deterioração da obra, que se encontra em seu original com as páginas soltas, e pela ausência de numeração nestas, seria impossível de determinarmos o seu local exato no conjunto da obra no caso o chamado álbum do Maranhão. Os álbuns, como afirma André Rouillé (2009), teriam a função de inventariar e ordenar o mundo. A ideia de ordenação do mundo certamente nos remete a ideia de direcionamento do olhar, construído a partir das escolhas do fotógrafo como afirma Samain (2012) a fotografia deve sua existência a múltiplos fenômenos que se combinam:

Para se moldar foi preciso um suporte: uma máquina de luz, jogos de lentes, diafragma e obturador, uma placa sensível. Para se construir, precisou de uma pessoa, do seu talento, de sua maneira de observar, de pensar e de expressar o que viu, de enquadrar, de recortar, de manipular. Para emergir, ela precisou da existência do tempo, do espaço, da luz e da sombra, das cores, das linhas, dos volumes, das formas, do ambiente. Em poucas palavras, a fotografia precisou da longa história da "aventura icônica". (SAMAIN, 2012, p. 157)

Como podemos constatar, para embarcarmos nessa aventura icônica como nos convida Samain, será preciso nos aventurar por caminhos diversos, em meio a técnica, ao observador, ao tempo, ao espaço, tendo que realizar uma operação de montagem, desmontagem e remontagem do objeto histórico como sugere Huberman (2011). A operação de desmontagem do nosso objeto, no caso a fotografia Porto do Maranhão, presente no Álbum do Maranhão de 1908, encontra-se inserida no universo de 220 imagens que compõe a série. Nossa intenção neste ensaio será identificar possíveis sobrevivências acerca da criação de uma espécie de silhueta da cidade que irá atravessar os tempos e que será reatualizada em diferentes épocas no movimento dialético. Não se trata aqui de irmos à busca de uma origem como gênese, mais como nos explica Didi-Huberman (2011, p. 128) ao apoiar-se em Benjamin:

A origem, mesmo sendo uma categoria plenamente histórica, não tem nada a ver com a gênesis. Por "origem" não se entende 
retornar a algo que havia surgido, e sim o que está em caminho de ser no devir e no declinar. A origem é um redemoinho no rio do devir, e estranha em seu ritmo da matéria do que está em vias de aparecer. A origem nunca se dá a conhecer na existência desnuda e manifesta do factual, em seu ritmo não pode ser percebido, mas que em uma dupla ótica. Chamada para ser reconhecida por uma parte como uma restauração, uma restituição, e por outra como algo que desse modo está inacabado, sempre aberto. [Tradução nossa]

Para restaurarmos uma pré-visão significa mergulharmos num conjunto de reminiscências que sobreviveram há diferentes tempos como uma imagem dialética, nos termos pensados por Benjamin, de modo a promover "um encontro de tempos heterogêneos, que ao se chocarem forma uma constelação" indiscernível entre presente e passado (TAVARES, 2012, p.5). De modo a compreendermos o circuito que integram a construção do olhar, acerca das silhuetas (paisagens) de São Luís, talvez seja necessário entendê-las como aquilo que possibilita a transmissão de uma memória coletiva que atravessa transversalmente a história da cidade.

As vistas topográficas da cidade de São Luís serão profundamente marcadas por uma visualidade que podemos denominar de estrangeira na medida em que expressam certo distanciamento no modo de compor a paisagem, além de serem predominantemente obra de estrangeiros de fato, onde as imagens do porto, do mar, da costa evidencia-se como uma alegoria do não pertencimento daqueles que chegam, funcionando como a sua primeira impressão, sua primeira mirada, uma porta de entrada que convida aos navegantes a atracarem. No segundo texto que compõe a trilogia da Crônica Berlinense Benjamin volta-se para a questão da percepção da cidade estabelecendo uma diferenciação acerca daquilo que ele classificou como o olhar do autóctone e olhar do estrangeiro, para ele "[...] conforme o lugar de nascimento do autor, percebemos que os escritos por autóctones são minoria. O motivo superficial, o exótico, o pitoresco só atrai os de fora. [...]." (BENJAMIN apud BOLLI, 1994, p. 316). Da mesma forma se nos voltarmos para o campo da imagem, que tem como temática a cidade de São Luís, verificamos que a memória imagética desta, em sua maioria vai ser elabora pelo olhar do estrangeiro, não necessariamente vindo de outro país, mais de outra cidade ou estado.

Se adentrarmos no redemoinho temporal do processo de composição de uma imagem da cidade de São Luís, caminha- 
remos em direção a processos circulatórios de modo a percebermos uma troca nos modos de olhar à cidade. Para esboçarmos uma arqueologia da imagem do Porto do Maranhão composta por Gaudêncio Cunha, remontaremos as primeiras imagens instituídas como as imagens fundadoras da cidade de São Luís. Como já dito anteriormente não se trata de voltar a origem pensada como gênese de modo a remeter-se a um tempo linear mas sim a ideia de noção de origem como restauração inacabada e aberta (DIDI-HUBERMAN, 2001, p. 109).

Trata-se de uma imagem forjada no território da descrição, no momento da chegada dos franceses que aportaram no Maranhão em 1612, data considerada oficial segundo a historiografia tradicional para a fundação da cidade de São Luís, refiro-me à narrativa elaborada pelos padres capuchinhos que deixaram seus relatos na obra História da missão dos padres capuchinhos na ilha do Maranhão, nas palavras de seu autor Claud D'Abbeville:

\begin{abstract}
Desejando os Srs. De Rasilly e Lar Ravardière construir um forte para a segurança dos franceses e conservação do país, escolheram uma bonita praça para esse fim, muito própria por ser uma alta montanha, e na ponta de um rochedo inacessível, superior a todos os outros, e de onde se descobre terreno a perder de vista, e embora separada da terra firme, é inconquistável e muito forte, pois está cercada de dois rios profundos e largos, que desembocam no mar ao pé do dito rochedo, onde é o único porto da ilha do Maranhão, e nele podem fundear com toda a segurança navios de mil a mil e duzentos toneladas. (D'ABEVILLI apud CARVALHO NETA; CANTANHEDE, 2012, p.25-26).
\end{abstract}

A polêmica citação de D'Abville já provocou intenso debate mobilizado pela recente historiografia acerca da possível origem francesa da capital maranhense. Segundo a historiadora Lacroix (2008) o mito da fundação francesa da ilha de São Luís teria sido inventado por uma corrente de intelectuais que no início do século XX, instituíram os ritos comemorativos acerca do tricentenário de fundação da capital maranhense, baseada numa revisão historiográfica, realizada anterior à invenção proposta pelo grupo dos "novos atenienses", Lacroix não encontra qualquer menção entre os historiadores que trataram sobre o tema anterior à geração de 1912. Justifica-se dessa forma, a origem luso-espanhola considerando que na época da fundação da cidade, Portugal encontrava-se sob o julgo da 
culatório de troca efetiva de influências artísticas entre outras obras de arte que contribuirão para compor um registro visual de São Luís, desse modo merecem atenção por inaugurarem um olhar acerca do espaço que sustentará uma corrente mimética representativa sobre a cidade. Esse espaço descrito pelos franceses será complementado por representações corográficas importantes que ampliarão nosso olhar sobre a cidade, a partir dos registros feitos pelo arquiteto e engenheiro militar Francisco Frias de Mesquita, e ao cartógrafo português João Teixeira Albernaz.

Paulo Santos (2001) em sua obra denominada Formação de Cidades no Brasil Colonial, afirma que as cidades brasileiras entre o século XVI e XIX serão fruto de alguns imperativos responsáveis por suas existências, no caso de São Luís do Maranhão, o autor a classifica como uma cidade de defesa, e afirmação de posse como a maioria das cidades do litoral no inicio do período colonial. Com relação à de São Luís, seu traçado começa a ser gestado a partir da planta elaborada pelo arquiteto e engenheiro militar Francisco Frias de Mesquita, que no século XVI acompanhou a jornada de reconquista do Maranhão comandada pelo português Jerônimo de Albuquerque, que visava retomar a região que se encontrava em poder dos franceses em 1612, tendo este, participação efetiva na missão, construindo um fortim a partir de onde os portugueses puderam se organizar para enfrentar o inimigo. A essa altura, Frias de Mesquita tinha muita experiência ao acabar de concluir o projeto do forte dos reis magos em Natal.

Segundo Sousa (ANO), a planta acima, existente no livro panegírico publicado em 1647, de autoria do teólogo e historiador holandês Caspar Barlaeus, traz uma planta que se acredita ser a tradução mais próxima da traçada elaborada por Frias, já que não se tem notícia da original idealizada por este.

Outra personalidade que contribuirá sobre maneira para instituir uma visualidade sobre a região será o cartógrafo Teixeira Abernez, o velho, como assim o chamavam para que se possa diferenciá-lo do sobrinho homônimo, ao qual mais tarde daria continuidade à tradição cartográfica da família. A obra de Albernez surpreende pela riqueza de detalhes nela descritos, onde seus mapas podem ser vistos como telas pintadas de modo a figurar como uma das peças do atlas visual da memória da cidade.

Membro de uma tradicional família de cartógrafos portugueses, Teixeira Albernez é autor de duas importantes obras cartográficas, uma dedicada ao Maranhão, o Atlas do Maranhão, que segundo Maranho (2010) estaria associado às incursões francesas sobre a região, além de 19 atlas e 6 cartas, onde

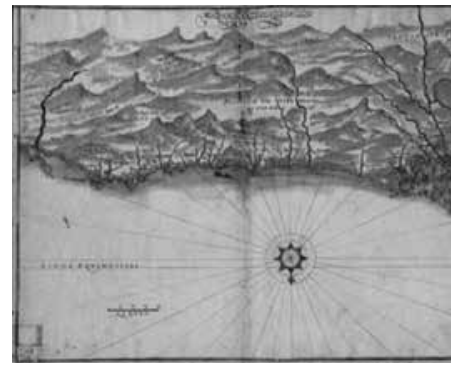

Figura 4

Planta do litoral maranhense, atribuída a Albernez I, 1629.

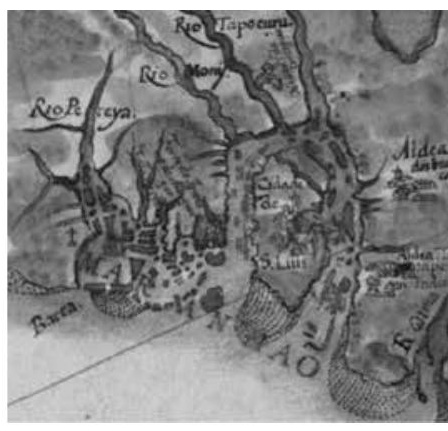

Figura 5

Detalhe da planta de Albernez I 
alguns destes mapas foram feitos para ilustrar a obra Livro que dá razão ao Estado do Brasil de autoria do Sargento Mor Diogo de Campus Moreno em 1612, assim como para compor a crônica da situação presente naquela região do então governador Geral do Estado do Brasil Diogo Menezes e Siqueira, Maranho (2010, p. 6) ao citar Back afirma que os mapas antigos que diz respeito a América Portuguesa no século XVII:

[...] são "imagens visuais [...] [que] influenciam na criação e sustentação de noções de situações históricas". Circunstâncias nas quais as imagens são utilizadas como meio de criar percepções de poder e, de modo mais geral, [elas demonstram] ênfase em aspectos iconográficos da autoridade política e cultural que se quer retratar.

A importância tanto da primeira traça atribuída a Francisco Frias, como da cartografia desenvolvida por Teixeira Albernaz, reside no fato delas instituírem uma visibilidade para o espaço representado, dessa forma atribuindo significado ao espaço.

Para além dos registros que se tomou conhecimento a partir da ocupação francesa, outros importantes serão assinalados com a ocupação holandesa em 1641. Ainda segundo Casper Barlaeus, encontramos um importante registro visual atribuído ao pintor holandês Frans Post, a gravura encontra-se no livro de Barlaeus e se assemelha às demais, que fazem parte do restante da obra.

Figura 6

Frans Post, Vista de São Luís (1642)

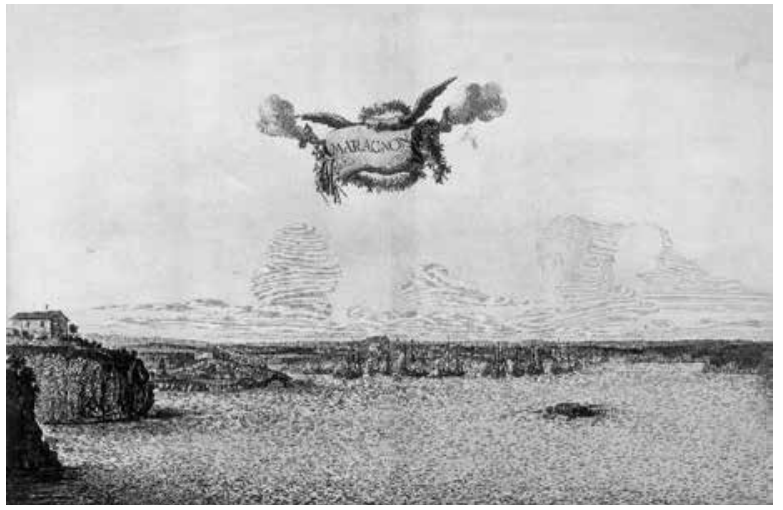

Nascido na cidade de Harleem, Post era filho de um pintor de vitrais, onde a princípio pensou-se que este viesse a ser o seu mestre, contudo, este faleceu quando Post tinha apenas dois anos de idade, a seu respeito sabe-se ainda que seu irmão 
Piter Post também era pintor e arquiteto, o que evidencia segundo Laura Reviglio (1970) que a princípio este faria parte de uma família de artistas, nascido num ambiente de efervescência da pintura holandesa, já que a sua cidade natal abrigava importantes artistas como Thierry Bouts, Jean Mostaert, Cornelis dito de Haarlem como afirmou a autora supracitada: "Um ambiente favorável a sua formação artística não pôde, além disso, faltar-lhe, tenha ele estudado em Leyden ou em Haarlem. Pode-se dizer que estas duas cidades são os focos primitivos da pintura holandesa”. (REVIGLIO, 1970, p. 8).

Segundo Carvalho Neta e Cantanhede (2012, p. 52), a gravura "foi inicialmente trabalhada na forma de desenho, depois em óleo sobre tela, e finalmente em gravura e metal." Trata-se de uma gravura que retrata a costa da ilha do Maranhão, aparentemente feita a partir da localidade com a qual descrevia os franceses, quando ocuparam a região. Sobre este ponto existem discordâncias entre os leitores da imagem acerca do local preciso que a imagem retrata. Para os autores acima citados a obra de Frans Post "[...] mostra a cidade de São Luís a partir da entrada da Barra, ressaltando a região da Ponta D’Areia, Ponta do Morro (hoje São Francisco) e Rio Bacanga, num amálgama de terra e água." (CARVALHO NETA; CANTANHEDE, 2012, p. 53). No entanto, Espírito Santo (2006, p. 379) defende que "[...] a imagem foi capturada da entrada da barra, no momento em que a esquadra holandesa tomava o porto maranhense, no trecho hoje compreendido pelo Portinho (Terminal de pesca da cidade)". Polêmicas à parte acerca da localização precisa que a obra retrata, o importante é que entendamos que a tradição holandesa de pintura de paisagem inaugura em território brasileiro um gênero que mais tarde influenciará sobremaneira a fotografia.

Segundo Etcheverry (2007, p. 49) "a paisagem da cidade aparece na pintura esparsamente até o século XVII, quando se torna um gênero pictórico independente com a pintura holandesa". Kennet Clark divide a pintura de paisagem em duas fases importantes: uma que segundo ele demarcaria o momento em que o homem mostrava-se temeroso diante desta, o que seria reflexo do predomínio de uma mentalidade medieval, implicando na elaboração de uma paisagem dos símbolos. Onde esta, aparecerá apenas como pano de fundo associada a uma cenografia de efeito dramático, e num segundo momento, ela irá apresentar-se menos imaginativa e com ênfase em aspectos mais factuais e urbanos o que ele denominaria de paisagem dos fatos. (CLARK apud ETCHEVERRY, 2007). 
De acordo com Clark nessa nova fase iniciada no século XVII, devido a fatores sociológicos, filosóficos e imanentes à própria arte, o homem vai mostrar-se mais aberto ao mundo exterior devido ao fortalecimento da burguesia (explicação sociológica), a um maior conhecimento da natureza com o florescimento da ciência (explicação filosófica), e por fim devido ao esgotamento de uma arte de caráter maneirista, (explicação no campo da própria arte). (ECHEVERRI apud CLARK, 2007).

Neste sentido, as explicações de Clark, se desconsiderarmos o apego a uma temporalidade linear, nos permite olhar para a gravura elaborada pelos franceses no início do século XVII (figura 2), como uma paisagem de caráter mais simbólico, já que a paisagem é apresentada nessa obra como pano de fundo, e com um forte apelo dramático ao reproduzir uma cena idealizada, que simbolizaria a união entre índios e brancos entorno do ideal cristão representado pelo hasteamento da cruz.

Já a gravura de Post em estudo (figura 6), poderia ser pensada segundo esta base conceitual como uma paisagem dos fatos considerando que a mesma faz alusão à ocupação de um território por parte dos holandeses, que permaneceram no Maranhão entre 1641 a 1644. Por conseguinte, no que tange a gravura de Frans Post sobre a tomada da ilha do Maranhão, poderíamos por hora considerá-la como uma referência para as demais obras representativas da mesma temática.

Após a expulsão dos holandeses do Maranhão, assistiremos um hiato no que diz respeito à produção de novas vistas da cidade, não só nesta região, como em todo o Brasil. tal fenômeno segundo Echeverry (2007) se dará devido ao fator proibitivo imposto pela coroa portuguesa, tal situação só se alteraria em 1816, ano em que chegaria ao Brasil a missão francesa, com o intuito de desenvolver as artes em território brasileiro. De acordo com Trivelato (2009, p. 4) "o século XIX foi o século da paisagem, elas davam conhecimento abrangente dos lugares. O pitoresco buscava consumir o mundo das paisagens ensinando a elite letrada brasileira a aprender a olhar o próprio país com suas grandes vastidões."

Pelo que se tem notícia, não existe registro da presença dos ilustres membros da missão francesa pelo o Maranhão no Século XIX, contudo marcou presença na província nomes como o italiano Joseph Leon Righini, que segundo Carvalho Neta e Cantanhede (2012), chega a São Luís acompanhando de uma companhia lírica italiana na qualidade de cenógrafo em 1856, e devido a desentendimentos com o empresário desta, resolve deixá-la e fixar residência na capital maranhense, ficando até 
1856, ano em que se muda para Belém. Righini nos legou diversas vistas da cidade de São Luís durante a sua passagem pela cidade, esse olhar estrangeiro interessara-se muito mais pela paisagem natural, exótica e pitoresca, sem deixar de voltar-se para o espaço que historicamente vinha sendo forjado ao longo do tempo, num jogo dialético entre presente e passado.
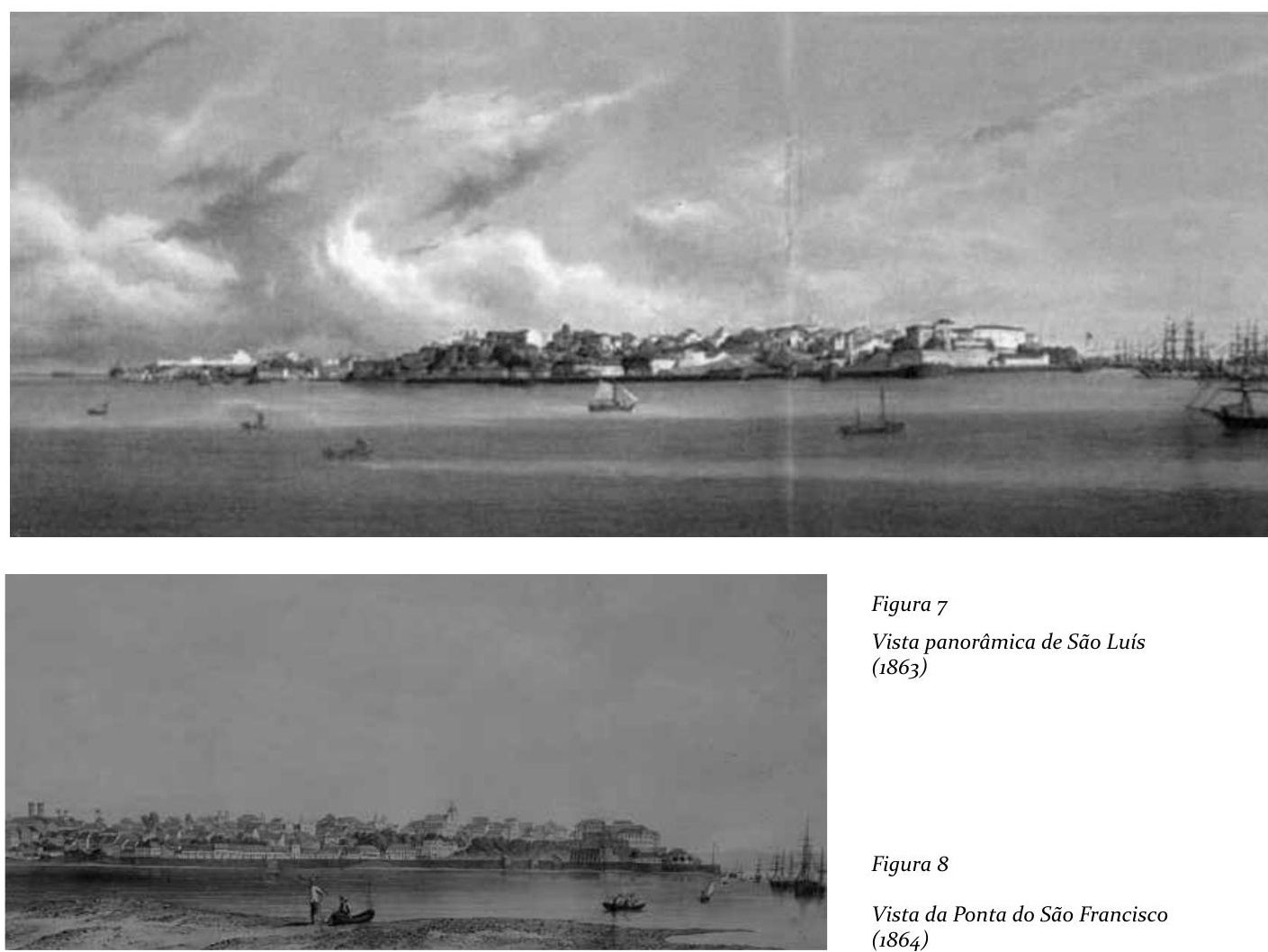

Figura 7

Vista panorâmica de São Luís (1863)

Figura 8

Vista da Ponta do São Francisco (1864)

Outra obra que ganhou bastante notoriedade é atribuída aos litógrafos alemães Muller e Gluck, uma das vistas mais divulgadas sobre São Luís, feita em litografia a partir de uma pintura de Manuel Ricardo Couto, embora no ano de 1865, a fotografia já houvesse se popularizado na capital maranhense, a imagem se notabiliza fazendo parte da coleção particular do poeta e teatrólogo maranhense Artur Azevedo.

Ao retomarmos a hipótese interpretativa inicial alicerçada na concepção benjaminiana de origem, conclui-se que as vistas de Leon Righini, Muller, Gluck, Frans Post e Gaudêncio Cunha, podem ser pensadas como camadas de tempo em torno de uma 
mesma visualidade sobre São Luís do Maranhão, que se renova constantemente e ajuda a definir um atlas da cidade a partir do olhar de quem chega, um olhar estrangeiro responsável por trocas culturais que ajudam a compor o mosaico cultural da cidade, que tem nas vistas panorâmicas que trazem à mesma como tema, visões que unificam e conformam um olhar sobre esta, revelando o poder uniformizador das vistas que corrigem às diferenças morfológicas do tecido urbano.

Este constante atualizar do primitivo promove diretamente um diálogo entre mapas, fotografias e vistas pictóricas que fazem parte do repertório visual da cidade retomado a partir dessas sobrevivências, que se atualizam e retrabalham uma ideia inacabada de uma imagem acerca da Ilha do Maranhão.

\section{Referências}

BENJAMIN, Walter. Pequena história da fotografia. In: Magia e Técnica, Arte e política-obras escolhidas I. Trad. S. Rouanet, São Paulo: Brasiliense, 1985.

BOLLE, Willi. Fisiognomia da metrópole moderna: Representação da História em Walter Benjamin. São Paulo: Editora da Universidade de São Paulo, 1994.

BRIZUELA, Natalia. Fotografia e Império: paisagens para um Brasil Moderno. São Paulo: Companhia das Letras; Instituto Moreira Salles, 2012.

CARVALHO NETA, Raimunda N. Fortes; CANTANHEDE, João C. A cidade e a memória: as representações artísticas formando a identidade ludovincense. São Luís: editora da UEMA, 2012.

CRARY, Jonathan. Técnicas do observador: visão e modernidade no século XIX. Rio de Janeiro: Contraponto, 2012.

DIDI-HUBERMAN, Georges. A imagem Sobrevivente: história da arte e tempo dos fantasmas segundo Aby Warburg. Rio de Janeiro: Contraponto, 2013.

. Ante el tempo: historia del arte y anacronismo de las imágenes. Buenos Aires: Adriana Hidalgo editora, 2011.

. Diante da imagem. São Paulo: Editora 34, 2013. Imagens apesar de tudo. Lisboa: KKYM, 2012.

ESPIRITO SANTO, José Marcelo. (Org.). São Luís: uma leitura da cidade. São Luís: Prefeitura Municipal de São Luís/Instituto de Pesquisa e Planificação da Cidade, 2006.

ETCHEVERRY. Carolina Martins. Visões de Porto Alegre nas fotografias dos Irmãos Ferrari (c.1888) e de Virgílio Calegari (c.1912). Dissertação de Mestrado. Porto Alegre: Universi- 
dade Federal do Rio Grande do Sul, 2007.

LACROIX, Maria de Lourdes Lauande. A Fundação Francesa de São Luís e seus Mitos. 3. ed. São Luís: UEMA, 2008.

MARIN, Louis. Ler um quadro. Uma carta de Poussin em 1639. In: CHATIER, Roger. Práticas de leitura. 4. ed. São Paulo: Estação Liberdade, 2009.

PINTO, Dalila dos S. C.; TÁVORA. Maria Luísa Luz. Sobrevivência da imagem: o anacronismo na gravura de Marcelo Grassmann. Palíndromo teoria da história, Florianópolis, n. 3, 2010. Disponível em: <http// www.ppgav.ceart.udesc. br> . Acesso em: 26 jun. 2014.

MARANHO, Milena Fernandes. Retratos da colonização: Os mapas dos Teixeira Albernaz e a construção dos sentidos da América portuguesa seiscentistas. In: $3^{\circ}$ Simpósio Iberoamericano da História da cartografia, 2010, São Paulo: USP, 2010, p. 01-17.

PUGLEISE. Vera. O anacronismo como modelo de tempo complexo da espessura da imagem. Palíndromo teoria da história, Florianópolis, n.6, 2011. Disponível em: <http// www.ppgav.ceart.udesc.br> . Acesso em: 25 jun. 2014.

REVIGLIO. Laura. Frans Post - O primeiro paisagista do Brasil. Revista do Instituto de Estudos Brasileiros, São Paulo: USP, 1970. Disponível em: < http//www.ieb.usp.br >. Acesso em: 21 jun. 2014.

ROUILLÉ, André. A fotografia: entre documento e arte contemporânea. São Paulo: Editora SENAC, 2009.

SAMAIN, Etienne. As peles da fotografia: fenômeno, memória/arquivo, desejo. Visualidades, Goiânia, n.1, v.10, jan-jun. 2012. Disponível em: <http:// www.revistas.ufg.br>. Acesso em: 15 jun. 2014.

SANTOS, Paulo Ferreira. Formação de cidades no Brasil colonial. Rio de Janeiro: Editora da UFRJ, 2001.

SILVA FILHO, José Oliveira da. A história capturada: São Luís pelas lentes de Gaudêncio Cunha. São Luís: EDUEMA, 2012.

TAVARES, Marcela Botelho. $O(s)$ Tempos(s) da imagem: uma investigação sobre o estatuto temporal da imagem a partir da obra de Didi-Huberman. Dissertação de Mestrado. Ouro Preto-MG: Universidade Federal de Ouro Preto, 2012. TRIVELLATO, Fred Teixeira. O Brasil das pinturas e fotografias de viajantes: geografias, narrativas e imagens do Brasil. II Encontro Nacional de História do Pensamento Geográfico. 2009, Campinas: UNICAMP, 2009. Disponível em: <http// www.enhpgii.files.wordpress.com>. Acesso em: 01 jul. 2014. 
VIEIRA. Daniel de Souza Leão. A topografia ausente: a paisagem poliítica da Nieuw Holland nas vinhetas de Frans Post para o Mural Brasilia Qua Parte Paret Belgis, 1643-1647. Clio Revista de Pesquisa histórica, Recife, n. 29.1, 201. Disponível em: <http//www.revista.ufpe.br>. Acesso em: 22 jun. 2014. WARBURG. Aby. Dürer e a antiguidade italiana. Cadernos Benjaminianos, Belo Horizonte, n.5, p. 66-72, jan./jun. 2012.

Recebido em: 27/02/15

Aceito em: 23/03/15 
JOSÉ OLIVEIRA DA SILVA FILHO

joseoliveira@ifma.edu.br

O autor é docente no Instituto Federal do Maranhão-IFMA, Mestre em História e atualmente cursa doutorado em História pela PUCRS. Em 2012 publicou o livro: A Historia Capturada: São Luís pelas lentes de Gaudêncio Cunha (1895-1908). É Pesquisador associado ao Laboratório de Pesquisa em História da Imagem e do Som da PUCRS. 